\title{
A STORY OF GROWING UP: HUNGARIAN BANKING SYSTEM
}

Éva Várhegyi

\begin{abstract}
Reborn three decades ago, the Hungarian banking system has gone through significant changes over the course of a generation. All kinds of genetic defects and acquired illnesses hampered its development, while the external environment did not always prove "friendly" towards it; for this reason, it stalled and even regressed from time to time. Despite this, it largely rid itself of its bad inheritance, made it through the difficult transformation of its adolescence (privatization), and - on reaching adulthood - more or less weathered the hardships that rained upon it in the wake of the international credit crisis.

In this article, we review the decisive milestones in the 30-year evolution of the Hungarian banking sector: the formation of the two-tier banking system; the consolidation of banks that partly corrected unfavourable legacies from the past; the laborious, politically charged decision-making process of privatization; the sell-offs of banks that resulted in foreign dominance of the ownership structure; the rush and rivalry of banks freed from various fetters; the crisis that put the bridle on this mad canter; and finally, the government's "national" banking policy, which entered the scene in 2010 and once again appears to be amplifying the previously reduced moral hazard.
\end{abstract}

JEL codes: D43, Go1, G21, N24

Keywords: banking system, privatisation, competition, crise

\section{CONCEPTION - WITH GENETIC DEFECTS}

At the time of the "conception" of the two-tier banking system as one compatible with the market economy in 1987, a couple of years prior to the change of political system, the legacy of the past could not be removed. The ownership background, with its built-in conflict of interest, together with the potential for political pressure, the weakness of regulation and the growth fever driving bank leaders, would in themselves have been sufficient to plunge the three successor banks of the National Bank of Hungary (MNB) into inevitable crisis. However, besides the deficiencies acquired as the 1980s turned to the 1990s, these banks were also 
burdened by long-standing legacies, or genetic defects if you will. In addition to a clientele on weak foundations, and with the stock of credit previously extended by the MNB having little chance of being repaid, the shortage of capital was also a burden bringing its own awkward set of problems.

The commercial banks detached from the MNB - the Hungarian Credit Bank (Magyar Hitel Bank, MHB), the National Commercial and Credit Bank (Országos Kereskedelmi és Hitel Bank, OKHB) and Budapest Bank (BB) - took over the loan stock of the MNB's previous lending divisions, together with the credit lines that served as their sources of refinancing. Their provision with capital, however, was treated as a secondary issue. In 1987, the three successor banks had combined equity capital of barely HUF 20 billion, while the sum total of their outlays reached HUF 450 billion. Although in the following years the gearing ratio was reduced, partly as a consequence of capital raises and partly due to increasing accumulated assets and reserves, even the banks' swollen combined equity capital of HUF 44 billion was inadequate compared to the scale of risk inherent in their outlays. The government's financial leaders themselves made the situation worse in 1989, eliminating the possibility of accounting risk provisions as expenditure. The impact of short-sighted fiscal policy was precipitated in the banking crises of the 1990s, significantly increasing the rescue costs.

The problems with capital that later manifested themselves at the successor banks were only partly a consequence of not receiving adequate capitalization in 1987 , however. The deficiency was further exacerbated by the weak capital situation of the banks' clients, the cause of which goes back to the one-sided reform of 1968 , when the MNB used working capital loans to bridge the shortage of capital at more or less independent companies, which then became incorporated into the companies' liabilities as a practically constant element. The debt-burdened clientele and the banks' inadequate capital together represented a legacy that gave rise to problems which would only escalate further over ensuing years.

The contraction of the Hungarian economy and the appearance of signs of a transformative downturn began even before the change of political regime (Kornai, 1993). The country's GDP declined by $15 \%$ in the period 1988-1991, a process in which internal problems still played the decisive role, and which was only amplified by the collapse of Eastern markets that accompanied the democratic transformation. The problems emerging and worsening with the shrinkage of the economy were exacerbated by the internal weaknesses of the successor banks. The system of organisation and management of the newly formed banks, as well as their decision-making mechanisms, were inadequate for making prudent business decisions. The banks' managements were practically omnipotent, since the monitoring role of boards of directors and supervisory boards was generally only ceremonial. The weaknesses of internal and interbank information systems also 
contributed to the bad decisions. Internal decision-making mechanisms were often not linked into an appropriate framework of accountability, while internal regulations (debtor assessment, credit and investment manuals, etc.) were also lacking. The banks' internal weaknesses and inadequate interests added to the legacies inherited from inconsistent banking reform.

The capital losses pre-programmed into the MNB successor banks at the time of their creation, together with the inherited bad loans, were nevertheless only in small part responsible for the serious situation that developed by the beginning of the 1990s. ${ }^{1}$ One cannot disregard the hazardous business policy of certain bank leaders, which was characteristic not only of the successor banks, but also of newly established banks operating without sufficient owner supervision. At that time, the only institutions functioning under appropriate control were those in which foreign banks were the dominant owners.

The legacy of the rush for growth typical of the socialist economies endured after the change of political system wherever there was no strict owner supervision, and wherever bank leaders' sole indicator of success remained the given bank's economic weight, and the profit - albeit increasingly distant from reality - that it was able to show on paper. The fact that a significant portion of bank outlays offered not even the hope of recovery is well illustrated by the expansion of the banks' activities far in excess of the growth of the economy itself. While the Hungarian economy shrank sharply as the 1980 os turned to the 199os, and a great many companies appeared solvent only by virtue of circular debt, banks pursued their lending policy as if everything was in the best of order. The MNB successor banks, as well as OTP and MKB, expanded as if they remained the only competitors in the ring, while new banks emerging almost from nothing likewise produced spectacular growth at the end of the 1980s and early 1990s. In the period 1988-1991, the biggest dozen banks grew at a $15 \%$ faster pace than the economy in which they were operating. In reality, however, the surplus growth displayed on bank balance sheets continued to exist only on paper, evaporating with non-paying debtors.

\section{BANK CONSOLIDATION}

The symptoms of banking crisis soon appeared, although bank leaders momentarily attempted to disguise them in consort with politicians. They could not do so for long, however, since as early as 1991 the American media reported that certain Hungarian banks were in a state of "technical insolvency." Capital losses were truly pre-programmed. Júlia Király's hypothesis appears to be correct that

1 Estimates indicate that one third of bad loans derived from the stock of still unexpired or rescheduled credit taken over from the MNB. Cf. VÁRHEGYI (1995). 
the capital losses of banks fits into a kind of "spiralling crisis" process, "in which the capital losses of companies and banks mutually impacted one another, where the narrowing of the supply of bank credit could become a factor deepening the crisis" (Király, 1995).

The government endeavoured to break - or somewhat moderate - this "spiral" through a programme of loan, debtor and bank consolidation. Although the rescue effort was aimed directly at banks in particular, its reach extended to the whole economy. The crisis management process - launched belatedly due to the government's ostrich policy, and carried out with many anomalies - finally concluded successfully with the restoration of banks' lending capacity, an essential prerequisite for the functioning of the economy as a whole.

The first step, the undertaking of guarantees that can be regarded as offering only symbolic help, barely improved the situation of the banks concerned; moreover, the problems were only exacerbated further through 1992, with dubious or bad loans making up as much as one fifth of the total loan stock by the end of the year. The financial situation of debtors deteriorated dramatically, amplified by the collapse of eastern markets and the passing of the Bankruptcy Act. The next step was the so-called loan consolidation, within the framework of which some 18 banks and 68 savings cooperatives received government securities to the value of HUF 100 billion in exchange for the bad credit of almost 2,00o debtors. Since the buyout generally took place at a price of $80 \%$, banks were able to rid themselves of apparently irrecoverable receivables cheaply, to be replaced by non-marketable state securities of 20 years maturity earning interest at market rates. One year later, at the end of 1993, the government also aided some of the debtors themselves, as the state purchased the debts of a number of major state companies designated by the government (known as the "dirty dozen") from the banks at a rate of $90 \%$, after cancelling or rescheduling a portion of their debt to the state. The favourable effects of the debt relief nevertheless soon wore off for most of the banks - although it is true that the aim of the move was not to alleviate the burdens on banks, but rather to prevent the banks from being able to have a say as creditors in state decisions related to politically important companies.

Although the banks should have set aside increasing amounts of reserves to cover bad debts, they had no money to do this, since the 14 banks receiving aid produced combined losses of almost HUF 10 billion in 1992, while in 1993 their losses exceeded HUF 100 billion. The main problem, however, was the banks' shortfall of capital, which continued to grow despite the buyout of bad loans, exceeding HUF 100 billion by the end of 1993 . The World Bank, acting as an expert in the rectifying of the crisis situation in the Hungarian banking system, recommended a powerful capital injection as a remedy. 
In two steps (at the end of 1993 and in May 1994), the government appropriated government securities to the value of HUF 148 billion in giving the banks a capital injection that raised their capital adequacy ratio to $4 \%$, half of the ratio prescribed by law. In the absence of cash, it used government securities for the capital raises. In return for the capital raise, the banks had to conclude contracts with the Finance Ministry to participate in the so-called debtor consolidation process, within the framework of which each bank - based on corporate reorganization programmes - was able to cancel, reschedule or convert into ownership a portion of the debts of the companies concerned. The contracts also obliged the banks to elaborate a programme embracing improvements in cost management, rationalization of the organization, and enhancement of rating and credit review systems, completion of which would entitle them to a fresh capital raise in December 1994. Eventually, however, only the bigger banks received this much, allowing them to attain the capital adequacy of $8 \%$ prescribed by law, while the smaller banks were capitalized by the state only to the $4 \%$ level. During the two-year process of loan, debtor and bank consolidation, a total of HUF 425 billion worth of government securities, calculated at their 1994 value, were used by the government to aid the banks and their debtors. Half of the amount was used by the state to buy out banks' claims against debtors, while the other half was used to capitalize the banks.

To the question of whether the final bill for the major state bank rescue programme was too much, at around USD 4 billion or 10\% of annual GDP, more than one answer can be given. If we consider that this amounted to almost one tenth of the country's annual gross national product, then the burden seems considerable. If, on the other hand, we consider that without the state's rescue plan the banking system would have collapsed, and with it the entire economy, then we can safely say that the government chose the lesser of two evils.

\section{A DIFFICULT BIRTH: THE DECISION TO PRIVATIZE}

Once again brought under the strong influence of government through the rescue programme, the banks would not enjoy the warmth of the state's bosom for long, however: after a while, the "separation" of bank privatization would become inevitable. The Hungarian state itself, not enjoying particularly robust health, would have been unable to nurse so many hungry infants, not least as it was already apparent that they would never be suited to lead independent lives in the lap of the state. Even so, the decision on the method of privatization did not prove easy, since it needed to be taken within a forcefield of political and economic interests. Conceived with difficulty and bringing about large-scale changes, the decisions were nevertheless eventually vindicated with time, even if many harboured serious 
concerns about the large presence of foreign ownership in the Hungarian banking system.

The conspicuous dominance of foreign capital, not only in the Central and East European region but also on the global level, was engendered by twin pressures. On the one hand, the growing budget deficit meant privatization could not be delayed, even while there was an absence of capital-rich domestic investors who would have been able to inject money into the undercapitalized banks. On the other hand, the place of the state banks, which were shrinking and losing their markets, was being progressively occupied by the newly established subsidiaries of foreign banks. This in itself can be regarded as part of the privatization process, alongside the sale of the state banks, since the appearance of new banks also increases the ratio of private ownership in the banking system.

The Act on Financial Institutions, adopted in November 1991, finally took a position on the most fundamental matters of principle in the debates over bank privatization, with respect to the proportions of state and foreign ownership. After prolonged skirmishes, Parliament voted to extend the $25 \%$ limit on bank owners (whereby an owner's direct and indirect share of ownership - with the exception of another financial institution - could not exceed 25\%) to a general rule applying to the state as well. However, the law allowed the possibility of a postponement of privatization since it granted the state a five-year grace period to bring down its share of ownership.

The other dilemma of economic policy pertained to the attitude towards foreign investors. The protection of "national assets" arose particularly sharply with respect to major banks. The main argument was that large banks falling into foreign hands might traverse monetary policy by borrowing abroad. Those opposing foreign ownership also raised the spectre of profits generated in the banking sector, still (at that time) highly profitable due to distorted market conditions, being spirited from the country via foreign owners. As a final argument, the example of countries was raised in which the biggest banks were kept in national ownership until international competitiveness could be attained.

Eventually legislators opted for a fairly liberal solution. Although the law tied foreign acquisition of a share in ownership exceeding $10 \%$ to the government's prior consent in principle, it also set down criteria for the granting of permission that were easy to fulfil. At the same time, a proposal to limit the proportion of foreign ownership in the banking sector as a whole to $40 \%$ did not even make it into law. The Boross government's bank privatization strategy was eventually completed in February 1994, declaring that professional strategic investors should be sought above all. However, the time of the Boross administration saw the privatization of only one bank - the Hungarian Foreign Trade Bank (Magyar Külkereskedelmi 
Bank - MKB), which needed no state capital allocation. In the case of the other banks, the protracted process of bank consolidation and the banks' graver than expected capital position played their part in the delay.

Formed in the summer of 1994, the Horn government promised that bank consolidation would be completed with the capital allocations already promised by the preceding government. The privatization law did not, in the end, deal with the banks themselves, but merely determined that in future the government would decide on the method of bank privatization, the preparations of the banks, the selection of strategic investors, and the mode of sale. At the same time, according to the draft bill, it was symbolic that only two financial institutions - OTP and the MFB (Hungarian Development Bank) - featured among the companies remaining in long-term state ownership, and even in these the law prescribed a share in ownership of only $25 \%$ plus one vote.

The possibility was therefore open in principle for the sale of the banks. The problem increasingly took on a practical dimension, revolving around the question of how it was possible to find seriously-intentioned professional investors for banks that remained inadequately transparent even after restructuring, with risky receivables that were difficult to estimate. The sale of the upgraded banks consequently required additional state aid in almost every case. To ensure successful privatization, Budapest Bank received a capital reserve of HUF 12 billion from the government, based on a secret government decision, while the sale was tied to a HUF 8 billion asset repurchase guarantee granted to the bank's buyer. The state aided the merger of two capital-starved banks, Mezőbank and Agrobank, with a capital allocation to the tune of HUF 9 billion in 1995. In the spring of 1996, the state undertook a guarantee for bonds to the value of HUF 11 billion issued by Risk Kft., which was managing MHB's portfolio of bad debt, while the State Privatization and Holding Co. (ÁPV Rt.) and the MFB undertook portfolio swaps to help "dress up" the OKHB in 1997.

The persistent demands for support made it clear that as long as the privatization of the banks did not take place, there was not even a hope of stemming the flow of state aid. It was this recognition that contributed, at the end of 1994, to the Horn government setting as its objective the most rapid possible conclusion of the privatization process. Ideological and professional disputes reared up once again, however. The Finance Ministry urged the earliest possible privatization, thereby opening the way to professional and strategic investors. In contrast, an internal study by the ÁPV Rt. in the autumn of 1994 determined: "Instead of the largely hopeless search for strategic investors, partly motivated by partial interests (...) a public flotation is recommended. During privatization, the participation of domestic and foreign portfolio investors (foreign pension funds, institutional investors, domestic social security, insurance companies, local governments, etc.) is 
desirable." In the end, Parliament adopted a privatization strategy in 1995 that reflected the standpoint of the Finance Ministry, as it set down by stating that "during bank privatization, there is a need to primarily involve professional, strategic investors."

There were two exceptions to this. One was OTP, whose boss managed to avoid the involvement of foreign financial institutions in the bank, and besides retaining his seat as chairman and CEO, also maintained his influence in strategic decisions thanks to the evolution of a diffuse ownership structure. ${ }^{3}$ While concerns over such an ownership structure eventually did not prove justified in the case of the stock exchange-listed OTP, the story of Postabank served only to confirm them. Having earlier passed partly into the hands of foreign investors, Postabank was characterised by both a lack of proper supervision and a diffuse ownership structure, and - even despite its broken capital position - managed to evade the involvement of owners who might have exercised stricter control, leaving its boss free to run amok with fatal consequences (Várhegyi, 2002). Its genuine privatization occurred only after forced renationalization in 2002 (Király, 2005).

\section{THE CONVEYOR BELT OF SELL-OFFS}

The privatization of most members of the Hungarian banking sector was eventually completed more rapidly than the birth pains that preceded the decision. The first significant action was the partial sale of MKB in the summer of 1994, which was enabled partly by the bank's adequate status, and partly because the bank was less sensitive from a political point of view than OTP, with its concentration of retail savings, or the MNB successor banks that financed the greater part of large-scale industry and the agricultural sector. The first phase entailed the sale of a smaller portion of the shares, whereby the European Bank for Reconstruction and Development (EBRD) gained a role in the management of the bank alongside Bayerische Landesbank (BLB) as professional investor, something which offered BLB security since in this way it was not alone in having to bear the risks inherent in an unfamiliar bank. BLB acquired a share in ownership of $25.01 \%$ at this time, which was just enough to ensure that no strategic decision could be taken without it. The state retained for itself the same share, while the EBRD acquired a $16.7 \%$ stake, shares which the Bavarian owner bought out two years later by exercising its option in the second round of privatization.

2 As cited by MinÁLyi (1997:65).

3 A discussion of the "separate path" of OTP's privatization would stretch the boundaries of this article. For more detail, see VÁRHEGYI (2002:52-58). 
Of the banks offered for sale in 1995, only Budapest Bank was partly privatized, and only then with an additional helping hand from the state, with the bank receiving HUF 12 billion reserve capital from the government on condition that the amount would have to be repaid at the end of the year should the privatization fall through. Given that two suitors withdrew their interest in the purchase despite this dowry, the seller - keeping within its own tight time limits - was obliged to accept the only offer that allowed the sale transaction to go through before expiry of the capital loan deadline. Consequently, in December 1995, the EBRD and America's General Electric Capital (GEC) purchased a HUF 12 billion package of the bank's shares at face value, representing $60 \%$ of the total. As a result of the transaction, the EBRD acquired a $32.4 \%$ stake and GEC a $27.4 \%$ stake in the bank, as well as an option until 2001 for the purchase of the remaining state-owned package of shares.

Of the two main "stars" of the loan and bank consolidation, the privatization of MHB was the first to be carried out. The state helped clean the bank in advance of the bad loans that remained after consolidation, while the MNB freed it of the bulk of less liquid consolidation bonds. The new leadership taking on crisis management also endeavoured to make the bride more attractive by slimming down the extensive branch network and downsizing the workforce. These efforts bore fruit by autumn of 1996, when Western professional investors showed a great deal of interest in the sale of the bank. The best offer came from the Dutch ABN Amro Bank, which already had a subsidiary bank in Hungary: it promised USD 89 million for an $89 \%$ package of shares, together with an additional capital raise of USD 137 million. One year after the purchase, MHB was merged with the owner's local subsidiary, continuing thereafter to operate on the Hungarian market under the name ABN Amro (Magyar) Bank. Not for long, however: after three years vegetating and suffering losses of HUF 20 billion, it merged with $\mathrm{K} \& \mathrm{H}$, which had meanwhile passed into Belgian hands.

The sale of MHB broke the ice, as foreign financial institutions began to show interest in more and more Hungarian banks. For professional investors, this was the last chance to win markets by buying up clientele. Important mainly for its links with savings cooperatives, TakarékBank was the next to be sold in the spring of 1997. Obliged to reduce capital despite significant state assistance, the bank saw $61 \%$ of its registered capital bought by a consortium of Germany's DG Bank and insurer Hungária Biztosító, although following a necessary capital raise DG Bank acquired $90 \%$ of the bank, while $5 \%$ shares of ownership went to savings cooperatives and Hungária Biztosító. The same of Mezőbank also went quickly, incorporating Agrobank, a wide branch network and clientele. Some $84 \%$ of its shares were bought by Austria's Erste Bank, which also carried out a capital raise. The new owner of Mezőbank became the second largest bank in Austria at the time. 
The privatization of $\mathrm{K} \& \mathrm{H}$, which had secured a good market position with its broad range of clientele and extensive branch network, took place only in the autumn of 1997. Some $9.7 \%$ of the bank's capital, which had shrunk to just HUF 10.4 billion, a fifth of its earlier amount due to capital losses, was bought by the Belgian Kredietbank and insurer Irish Life, but the EBRD also took part in the purchase. As a result of capital raises, the stake of the Belgian-Irish consortium rose to $57 \%$, and the EBRD's to $17 \%$. The state eventually disappeared from the bank's ownership structure by the turn of the millennium, after K\&H suffered losses of HUF 10 billion in 1999, and with this its capital base also gave way. After the state as owner threatened to sell its share to the rival OTP, the Belgian owner shouldered the odium of K\&H's capital losses and gave the bank a HUF 10 billion capital injection.

The privatization of Hungary's banks was therefore largely complete by the end of 1997. In the meantime, in the first half of the 1990s, the MNB had divested itself of its interests in Citibank and Unicbank, and also parted with CIB in 1997. Besides the state banks serving government goals - the MFB, Eximbank, Földhitel- és Jelzálogbank (Land Credit and Mortgage Bank) - only a few small banks remained on the shelf (Konzumbank and Corvinbank, which were later merged and placed under the protective umbrella of the MFB). In 1998, with the state's rescue of Postabank from the brink of bankruptcy, the small group of state banks was augmented by one more institution. Even with this, the "removal of the state" from the banking sector proved a success, as the ratio of state ownership dropped below $20 \%$ and the weight of state banks on the market dropped back beneath $10 \%$.

The involvement of foreign investors in the privatization process and the newly established banks together created an unfamiliar ownership structure in the Hungarian banking system. Of the 42 credit institutions operating at the turn of the millennium, 32 were in majority, and one in minority foreign ownership. The share of majority foreign-owned banks in both the capital and assets of the banking sector reached two-thirds, and this subsequently increased further when OTP - with its $23 \%$ share of the market as a whole - also entered majority foreign ownership. The situation changed after 2010, however, when the Orbán government set as its goal the return of at least half of the banking sector to partial "national" ownership. 


\section{RUSH AND RIVALRY}

Following the turn of the millennium and right up until the escalation of the credit crisis of 2008, the largely privatized Hungarian banking system, adequately capitalized and with modernized services, lived through a golden age. Customers, too, were able to enjoy the benefits: although bank charges were higher than in Western countries, the range of available products and the standard of service were already approaching Western levels. To take one example, with development in Hungary having moved beyond the laborious system of cheques, customers already held almost five million bank cards in 2001, which they were able to use at 2,500 ATMs and POS terminals. Besides the increasingly wide range of modern products, banks strived to recruit and capture customers by opening branches at new, well-frequented locations (e.g. shopping centres).

Change was also manifested in the revival of competition between banks. At the start of the 1990s, newly established banks free of the bad legacies of the past were able to profit from their mere presence, without having to expend any great energy to lure customers away from the state banks and their low-quality services. From the mid-1990s, however, this strategy no longer paid off as the circle of banks building up a good professional background expanded, while banks cleansed and privatized with state assistance also regained strength. By the turn of the millennium, the Hungarian banking market had become the scene of a practically lifeand-death struggle, as the dog-eat-dog law of "devour or be devoured" took over. After bank privatization, few greenfield banks were created, which was primarily due to the saturation of the market and strengthening competition, but may also have been partly because in more advanced banking systems abroad the merger and acquisition processes had set off full steam ahead. The change of strategy was also apparent in the fact that foreign banks entering the Hungarian sector in the latter half of the decade had primarily started to target gaps in the market: it was this period that saw the establishment of "automotive banks" (Opel, Porsche), as well as credit institutions specializing in consumer lending (Cetelem) and home financing. The end of the decade also witnessed some exits (ING, Nomura, Citibank), although these generally did not signify total departure from the Hungarian financial market, but rather only the sale of certain branches of business or dropping of certain activities.

With the saturation of the corporate market and sharpening competition, the struggle also began in the retail lending segment as the new millennium approached, with more and more banks becoming active in this market. The appearance of competitors using well-advanced bank technology courtesy of their foreign professional backgrounds compelled the traditional retail banks to improve their services. With burgeoning competition came a leap in development in 
current account and bank card services, consumer lending, and the expansion of branch networks. The turn of the millennium brought a breakthrough in home lending, stimulated by the upswing in the economy, the stabilization of the real estate market, and the government's increasingly preferential system of interest subsidies.

The intensifying rivalry among banks was not without distortions, however. The structure of the banking market - which bore the hallmarks of inherited inequalities - initially led to limited competition, which - due to OTP's superiority deriving from its peculiar position ${ }^{4}$ - mainly characterised the retail market. Analyses examining the competitive conditions of the Hungarian banking market at the turn of the millennium pointed to a variety of distortions..$^{5}$ Among others, they observed that the Hungarian banking system's relatively weak efficiency by international comparison was coupled with high profitability, reinforcing the suspicion that, despite the favourable changes to the market structure, competition remained restricted. Model estimates showed a moderate degree of competition somewhat strengthening along the time axis in the period 1995-2002. Interest rates on the retail loan market were inflexible to rates on the money market to such a degree that they opened up the possibility of enforcing oligopolistic rent; moreover, the pricing of retail deposits also allowed scope for this.

The Expert Committee Examining Retail Financial Services, set up in the autumn of 2006, observed that "a number of problems hamper an increase in the degree of viable competition on the domestic retail banking market. These problems relate to market structure, market transparency, consumer protection, and the limited nature of the financial sector's intermediary role" (Bank Committee, 2006). The report also established that the dominance of OTP on the retail market opened the door to prevalence of the "leader-follower" model, which ensured a continuing high level of profit and modernization for the market-leading bank, while permitting profits for competitors covering the high costs of expansion.

Limited price competition did not, however, mean a total lack of competition, since non-price competition grew perceptibly in the 200os. Initially this was apparent in so-called cost-based competition, primarily embodied in the expansion of sales channels: in this context, banks' networks and headcounts increased significantly, as did their marketing activity. By developing their branch networks, banks previously active mainly on corporate markets targeted first the retail loan market, and later the market for deposits. In mid-decade, when forint-based mortgage lending ran out of steam due to the cutting back of interest subsidies on home loans, so-called risk-based competition gained ever-increasing ground,

4 For more on the special situation of the market-leading bank, see VÁrHEGYI (2011).

5 Móré-NAgY (2004); VÁrhegyi (2003). 
initially in forex lending, and subsequently with increasing client and lending risks (omission of income tests, increasing loan-to-value ratios, and increasing debt-to-income ratios) signifying the relaxation of prudent considerations. All this served to lessen the significant advantage of the market-leading OTP on the retail market, with a decreasing concentration particularly in the case of deposits and mortgage loans (Banai-Király-Nagy, 2010).

\section{THE CRISIS AND ITS MANAGEMENT}

The credit crisis of 2008 brought an end to the golden age of the Hungarian banking sector. The decline in banking activity was triggered not only by the crisis itself, but also by the Hungarian government's distinctive brand of "crisis management," which employed a variety of levies to narrow banks' room for manoeuvre and banking opportunities still further.

Hungary was among the countries hit hard by the international credit crisis, despite having played no part in either its initiation or spread. Hungarian banks bought and traded few or no "toxic" securities, and therefore did not contribute to the escalation of the liquidity crisis. Even so, because of the vulnerability of the economy and of the banks within it, the credit crisis impacted Hungary and its banking sector - with unusual force. ${ }^{6}$ This vulnerability can be largely attributed to an economic policy aimed at stimulating consumption in the period 2001-2006, which - besides leading to financial imbalances - spurred on a feverish expansion in lending at banks, raising the average loan-to-deposit ratio to $150 \%$ and increasing risks. In the competition for lending, banks paid increasingly little regard to the credit standing of borrowers, while continuously increasing the loan-to-value ratio and the duration of loans.

While the great majority of Hungarian banks were backed by West European parent institutions with a long-term commitment as owners, the financial crisis also placed them in a difficult position. Joint action by the banks most active in the Central and East European region, combined with a focus on longer-term interests among governments, supervisory authorities and leaders of the European Central Bank in the parent countries, as well as steps taken by central banks in the affected countries for the sake of forex liquidity, eventually softened the impact of the crisis on the region's banks. Foreign parent banks undertook a significant role in blunting the effects of the liquidity crisis, raising financing of their subsidiary banks, and - where necessary - ensuring the level of capital needed for safe operation through capital increases or profit reinvestment (Banai-Király-Nagy, 2010).

6 See mainly Király (2008); Király-Nagy-Szabó (2008); Surányi (2008); VÁrhegyi (2008), FENYŐ-VÁRHEGYI (2010). 
The crisis forced banks to adapt, embodied primarily in the reduction of the high loan-to-deposit ratio, a cutback in lending, and strengthening competition for deposits. Banks tightened their lending conditions (reducing the loan-to-value ratio, raising the own contribution requirement, making income tests universal once more in assessments of creditworthiness), while virtually freezing certain branches of business - primarily real estate project financing - by suspending lending. In some cases, wherever regulations or legal loopholes permitted such opportunities, already awarded loans were cancelled or contracts modified unilaterally to the detriment of the client. The spreading practice of unilateral modification of contracts met with growing disapproval from both regulators and public opinion in the spring and summer of 2009, speeding up the process - which had been dragging on for years - of creation of a code of conduct to function as a means of self-regulation in the banking sector.

The crisis launched a self-reinforcing process: the stalling and tightening of conditions for lending worsened the position of debtors, deepening the recession further, while the economic decline reduced banks' ability and inclination to lend, further exacerbating the contraction of the economy. Added to this was the short-sighted policy of the government coming to power in 2010 to increase its budgetary room for manoeuvre primarily by means of a special surtax on banks, among other financial burdens. There were a number of concerns that could be raised against the Hungarian bank tax introduced under the pretext of crisis in 2010. The glaringly excessive scale of the tax, both by international comparison and in light of the fundamentals of Hungarian banks, as well as the method of its imposition (with assessment based on the balance sheet footing for 2009), gave rise to capital losses at many institutions. At the same time, the subsequent imposition of tax on the activities of an already closed financial year violated legal certainty, while the principle of competitive neutrality was likewise damaged by the imposition of differing burdens on banks of different sizes. There was also a contradiction between the justification for the tax and the method of its application, inasmuch as the tax flowed into the budget, and not into a fund for management of a future crisis situation.?

The credit crisis that exploded in the autumn of 2008 , followed by the depreciation of the Hungarian forint in response to the strengthening of the Swiss franc from the summer of 2010, significantly increased the size of repayment instalments on previously widespread foreign currency-based loans (mostly in Swiss francs), and this soon snowballed into a serious social issue. Given the gravity of the problem, regulatory measures were adopted comparatively late in Hungary, and as a first step only put an end to Japanese yen-based lending, while Swiss

7 For more on the impact of the measures, see VÁRHEGYI (2011). 
franc loans expanded still further even in the couple of months after the outbreak of the credit crisis. It was only at the end of 2009 that the government issued a decree limiting forex lending (by which time practically all lending had come to a halt as a result of the crisis), while forex-based mortgage lending was banned in August 2010.

Measures aimed at helping forex debtors, however, shifted significant burdens onto banks already stricken by the excessive bank tax. The act on final repayment, entering into effect at the end of September 2011, compelled banks to accept outstanding repayments of forex loans in a lump sum at rates of HUF 180 to the Swiss franc and HUF 250 to the euro, while writing off the excess compared to the market exchange rates as losses. Given that only financially solvent clients with reserves were able to take advantage of the final settlement opportunity, the quality of the banks' remaining retail loan portfolios, and thus their incomegenerating capacity, deteriorated still further. The "clearing" act entering into effect in July 2014 placed an additional burden of some HUF 1 trillion on banks, obliging them to refund the surplus loan repayments they had obtained through unilateral modification of contracts. The flaw in the scheme was that under the law, the refunds applied retroactively to Hungary's accession to the EU in May 2004, even though the modification of contracts was regulated only in the act on credit institutions in force from 2010. Eventually, the problem of foreign currency loans was tackled effectively by Act CXLV of 2015 on the conversion of forex loans into forints, as a result of which some HUF 3.5 trillion worth of retail forex loans disappeared from the market. The double shock to Hungary's banking system - the crisis itself, followed by this distinctive form of "crisis management" - set back the performance of the sector conspicuously. By 2010, profitability had been reduced to practically zero, accompanied - despite capital injections by owners by deteriorating lending capacity. The ascendant phase of the 2000 s had come to an end, a "golden age" that was not only evident in the profitability of banks, but which brought major progress in all aspects of the Hungarian banking sphere, while signifying a great leap forward on the path of convergence with the developed regions of Europe. The parent institutions of Hungarian banks switched to an "operating mode" adjusted to the country's particular circumstances, which the president of the Hungarian Banking Association at the time characterised thus: "they stay, they bide their time, but they freeze their activity, turning their subsidiaries here into zombies" (Felcsuti, 2011). 


\section{IN THE SPIRIT OF “NATIONALIZATION”}

Besides the special bank surtax, most banks were put in a difficult situation by the stock of loan collateral (mainly commercial real estate) that began to depreciate in the wake of the ever-expanding economic crisis, as well as by the payment struggles of their clients. The often excessive risks undertaken during the "rush" of lending in earlier years (project financing, forex-based lending) compelled them to sharply cut back their balances from 2010. Government measures increasing the burdens on banks also made it harder to manage the crisis situation, necessitating additional injections of capital. In the six years of crisis, foreign owners carried out capital increases equivalent to more than HUF 1.5 trillion to cover losses at their subsidiary banks. This corresponded to roughly 5-6\% of annual GDP during the crisis, without which the economy might have collapsed.

While all this was happening, the Hungarian government was endeavouring to remodel the country's banking system and market positions under the rallying cry of "nationalization" of the banking sector. The goal proclaimed in the spring of 2010 was to raise the proportion of "national" banks to 50\%, which also applied to the majority foreign-owned OTP Bank and its quarter share of the market, as if it were controlling it from inside the country in the same way as domestically owned banks. This was not the only way in which the realignment became apparent, however. The government placed certain banks in the hands of new owners close to the seat of political power, striving to improve their position via various forms of government and central bank aid. Meanwhile, foreign subsidiary banks, already shrinking due to the crisis, were forced - by financial burdens that hit them the hardest ${ }^{8}$ - to cut back their activities still further, so that banks in "national" ownership preferred by the government were able to gain ground in parallel with foreign banks' displacement from the market.

In was in this spirit of "nationalization" that the Hungarian state purchased MKB Bank from its Bavarian owner, passing the bank into the hands of the MNB by means of the newly adopted law on resolution, before cleaning it up and reselling it through a new privatization procedure. This took place in 2016, although the bank's ownership structure has changed continually since, and at time of writing it is majority owned by business circles close to the prime minister. The present owners plan to list the bank on the stock exchange, although how realistic this is remains questionable. In 2015, Budapest Bank was bought by the MFB on behalf of the Hungarian government from its American owner GE, with the promise

8 The bank tax, calculated in proportion to balance sheet footing, determined a considerably higher percentage financial burden for larger, mostly foreign-owned banks than for mostly Hungarianowned smaller banks. 
that it would pass once more into private hands within three years at most. Al though the deadline has now passed, the fate of the bank remains unresolved.

With the same aim of raising the ratio of national ownership, the state agreed with the owner of Erste Bank to purchase a stake in the bank, accepting the condition that the EBRD also secure a similar 15\% share in the bank. The 2016 transaction is also significant because, parallel with the acquisition of a stake, the government undertook the obligation to refrain from regulatory action with a detrimental effect on the banking sector. During this period, "national" ownership was similarly strengthened by capital injections by the state into certain small banks close to the political powers-that-be, as well as indirect central bank support for their growth. Although radical transformation of the ownership structure of the savings cooperative sector was not guided by the "nationalization" narrative per se (since such institutions were domestic from the outset), the reform did enable the MFB to buy out the stake of Germany's DZ Bank in the umbrella bank of the savings cooperatives in 2012. The long-desired closer integration of the savings cooperatives was thus achieved centrally, reinforced by a capital injection of HUF 136 billion from the government. This came at a high price, however. With the forcible realignment of the ownership structure, the majority of cooperative members have lost or are losing their influence as the sector transforms into a "commercial bank" with a nationwide network, likewise controlled by economic forces close to the government, presumably with the intent to emerge as a rival of the biggest Hungarian banking groups.

As a consequence of the aforesaid transactions, the share of so-called nationally controlled credit institutions has risen within seven years by 13.5 percentage points to $55.7 \%$ according to market activity (balance sheet footing). ${ }^{9}$ From the perspective of the future stability of the banking system, two crucial questions arise: first, whether the newly "nationalized" credit institutions have sufficiently well-capitalized owners to stand firm should the need arise; and second, what is the impact on prudent bank operations of close interlocking with the centre of political power, and how much has the moral hazard been exacerbated.

\section{AFTERWORD}

After long years of adversity, the Hungarian banking system has undergone a revival, in which the improved economic climate has played its part, combined with the softening of regulatory pressure on the sector (with the reduced bank tax,

9 Source: MNB, https://www.mnb.hu/felugyelet/idosorok/i-penz-es-hitelpiaci-szervezetek/hitelintezetek. 
and an apparent inclination to reduce the duty on transactions), and the impact of banks' own efforts (e.g. to reduce costs). The majority of banks are generating substantial profits once more, albeit in significant part thanks to the freeing of earlier allocated reserves. The cleaning of bad portfolios is largely complete - with some work nevertheless still to be done on the retail front - and corporate and retail lending have relaunched, stimulated by the central bank and the state. Rising property prices have made project loans attractive once more, while growth in household consumption and the "disappearance" of previous debts also encourage lending. The question remains, however, of whether a renewed rapid expansion of credit will support sustainable economic growth, or only increase the risks once more.

Weighing the balance of a generation, we can by all means state that, despite unfavourable legacies and difficulties that have arisen in the interim, significant growth has occurred not only in quantitative, but also in qualitative terms. And yet it is still not easy to decide unequivocally whether the Hungarian banking system reborn 30 years ago is now able to "behave" in a responsible manner as a mature "adult," weighing the consequences of its decisions. Not that this is by any means peculiar to Hungary, since the credit crisis that broke out in 2008 clearly demonstrates that even in older banking sectors, irresponsible behaviour can easily take hold if not restrained by the external environment. All this serves to teach us the lesson that, in banking systems as in human lives, we cannot simply sit back contentedly and declare that we're wise enough now not to make mistakes. 


\section{REFERENCES}

Banai, Á. - KirÁly, J. - Nagy, M. (2010): End of the Golden Age in Hungary. "Foreign" and "Local” Banks - Before and After the Crisis. Közgazdasági Szemle, Vol. LVII, No. 2.

Bank Committee (2006): Proposals for the Management of Problems in Retail Banking Services. Expert Committee Examining Retail Financial Services, December 2003; http://misc.meh.hu/ letoltheto/Jelentes_bankibizottsag.pdf.

Felcsuti, P. (2011): Zombie Banks in Hungary. Portfolio.hu, 30 September 2011.

Fenyő, Gy. - VÁrhegyi, É. (2010): The Impact of the Crisis on the Banking Sector. Külgazdaság, Vol. 54, Nos. 3-4.

KirÁly, J. (1995): A Spiralling Crisis, or Making Sense of the Capital Losses of Hungarian Banks. Közgazdasági Szemle, Vol. XLII, No. 9.

KirÁly, J. (2005): A Bank that Stood Close by You. The Story of the Postabank Privatization, 20022003. Budapest, ÁPV Rt.

KirÁly, J. (2008): Liquidity in Crisis (Before and After Lehman). Hitelintézeti Szemle, Vol. 7, No. 6.

KirÁly, J. - Nagy, M. (2008): Mortgage Markets in Crisis: Risk-Based Competition and the Lessons Learned. Hitelintézeti Szemle, Vol. 7, No. 5.

KirÁly, J. - NAgy, M. - Szabó, E. V. (2008): Analysis of an Extraordinary Series of Events - the Crisis of Secondary Mortgage Markets and its Consequences (in Hungary). Közgazdasági Szemle, Vol. XLV, Nos. 7-8.

KornaI, J. (1993): A Transformative Downturn. Közgazdasági Szemle, Vol. XL, Nos. 7-8.

MiнáLyi, P. (1997): Lessons Learned from Bank Privatization. Külgazdaság, Vol. 41, No. 10.

MNB - National Bank of Hungary (2018a): Decree No. V-JÉ-I-23/2018 of the National Bank of Hungary on temporary measures applied against NHB Growth Credit Bank Zrt.

MNB - National Bank of Hungary (2018b): Resolution No. H-JÉ-I-B-166/2018 of the National Bank of Hungary on the closure of the supervisory process carried out at NHB Growth Credit Bank Zrt. with the employment of supervisory measures and a fine.

Móré, Cs. - NAgY, M. (2004): Competition on the Hungarian Banking Market. MNB Füzetek, $2004 / 9$.

SurÁnyi, Gy. (2008): The Mechanism of the Financial Crisis in the Developed and Emerging Economies. Hitelintézeti Szemle, Vol. 7, No. 6.

VÁrhegyi, É. (1995): Banks in Competition. Budapest.: Pénzügykutató Rt

VÁrhegyi, É. (2002): The Banking Sphere in Hungary. Budapest: Helikon Publishing.

VÁrhegyi, É. (2003): Bank Competition in Hungary. Közgazdasági Szemle, Vol. L, December 2003.

VÁrhegyi, É. (2008): Vulnerability and Credit Expansion in Light of Today's Crisis. The Validity of László Antal's Book. Hitelintézeti Szemle, Vol. 7, No. 6.

VÁrhegy , É. (2010): The Impact of the Crisis on Banking Competition in Hungary. Közgazdasági Szemle, Vol. LVII, October.

VÁrhegyi, É. (2011): Double Squeeze: Prospects of the Hungarian Banking Sector. Hitelintézeti Szemle, Vol. 10, No. 1.

VÁrhegy I, É. (2011): OTP as National Champion. Külgazdaság, 2011, Vol. LV, Nos. 7-8. 